\title{
ASYMPTOTIC EXPANSIONS OF BIVARIATE CLASSICAL MEANS AND RELATED INEQUALITIES
}

\author{
NEVEN ELEZOVIĆ AND LENKA VUKŠIĆ
}

Abstract. The subject of this paper are classical bivariate means and theirs behaviour for translated values of the arguments. The asymptotic expansions for eleven means are derived, with respect to the shift variable. This approach enables better understanding of various relations between these means.

Mathematics subject classification (2010): 26D15, 41A60.

Keywords and phrases: Asymptotic expansion; bivariate means.

\section{REFERENCES}

[1] U. ABEL, M. IVAn, A complete asymptotic expansion of power means, J. Math. Anal. Appl. 325 (2007), 554-559.

[2] J. ACZEL, Z. PÁLES, The behaviour of means under equal increments of their variables, Amer. Math. Monthly, 95 (1988), 856-860.

[3] P. S. Bullen, Averages still on the move, Math. Mag., 63 (1990), 250-255.

[4] P. S. Bullen, Handbook of Means and Their Inequalities, Kluwer Academic Publishers, Dordrecht, 2003.

[5] P. S. Bullen, D. S. Mitrinović, P. M. Vasić, Means and their inequalities, D Reidel, Dordrecht, 1988.

[6] Y. M. CHU, M. Y. SHI, Y. P. JIANG, Optimal inequalities for the power, harmonic and logarithmic means, Bull. Iranian Math. Soc. 38, 3 (2012), 597-606.

[7] Y. M. CHU, M. K. WANG, Z. K. WANG, A sharp double inequality between harmonic and identric means, Abstr. Appl. Anal. 2011, Article ID 657935.

[8] Y. M. ChU, M. K. WANG, Z. K. WANG, Best possible inequalities among harmonic, geometric and Seiffert means, Math. Inequal. Appl. 15, (2) (2012), 415-422.

[9] N. EleZović, Asymptotic inequalities and comparison of classical means, J. Math. Inequal. (to appear).

[10] N. Elezović AND L. VUKŠIĆ, Asymptotic expansions and comparison of bivariate parameter means, Math. Inequal. Appl., 17, 4 (2014), 1225-1244.

[11] N. Elezović, L. VuKŠIĆ Asymptotic expansions of integral means and applications to the ratio of gamma functions, Appl. Math. Comput. 235 (2014), 187-200

[12] A. ERdÉlyi, Asymptotic expansions, Dover Publications, New York, 1956.

[13] H. W. Gould Coefficient identities for powers of Taylor and Dirichlet series, Amer. Math. Monthly 85 (1978), 84-90.

[14] L. Hoenn, I. Niven, Averages on the move, Math. Mag., 58 (1985), 151-156.

[15] D. S. Mitrinović, J. E. PeČArić, A. M. FinK, Classical and New Inequalities in Analysis, D Reidel, Dordrecht, 1993.

[16] M. K. WANG, Z. K. WANG, Y. M. CHU, An optimal double inequality between geometric and identric means, Appl. Math. Lett. 25, 3 (2012), 471-475. 